\title{
Left ventricular pseudoaneurysm perceived as a left lung mass
}

\author{
Hafize Yaliniz ${ }^{1}$, Serafettin Demir ${ }^{2}$, Ugur Gocen ${ }^{1}$, Atakan Atalay ${ }^{1}$, Orhan Kemal Salih ${ }^{1}$ \\ ${ }^{1}$ Department of Cardiovascular Surgery, Faculty of Medicine, Cukurova University, Adana, Turkey \\ ${ }^{2}$ Department of Cardiology, Adana State Hospital, Adana, Turkey
}

Kardiochirurgia i Torakochirurgia Polska 2016; 13 (2): 157-158

\begin{abstract}
Left ventricular pseudoaneurysm is a rare complication of aneurysmectomy. We present a case of a surgically treated left ventricular pseudoaneurysm, which was diagnosed three years after coronary artery bypass grafting and left ventricular aneurysmectomy. The presenting symptoms, diagnostic evaluation, and surgical repair are described.
\end{abstract}

Key words: left ventricular pseudoaneurysm, lung mass, postaneurysmectomy.

\section{Introduction}

Acquired pseudoaneurysm of the left ventricle is a rare disorder that usually occurs after transmural myocardial infarction or after cardiac surgery [1]. The development of a pseudoaneurysm is a rare event after resection of a left ventricular aneurysm.

\section{Case report}

A 43-year-old man presented with retrosternal pain and dyspnea about 3 years after he had coronary artery bypass grafting and aneurysmectomy in another institution. On admission his physical examination was normal. His arterial blood pressure was 105/60 mm Hg, heart rate was 86 beats/min, and no cardiac murmur was noted. His chest X-ray showed an enlarged cardiac silhouette and also a poorly circumscribed basal mass in the left lung. Computed tomography however showed that the lesion perceived as a pulmonary mass in the roentgenogram was actually an antero-apical left ventricular pseudoaneurysm (Fig. 1). Two-dimensional echocardiography revealed the presence of a $10 \times 5 \mathrm{~cm}$ cavity communicating with the left ventricle through a hole in the antero-apical wall of the left ventricle measuring approximately $2 \times 2 \mathrm{~cm}$ (Fig. 2). This was also confirmed by left ventriculography (Fig. 3).

The operation was performed through median sternotomy with femoro-femoral cardiopulmonary bypass, moderate hypothermia and cold-blood cardioplegic arrest. After preparation of the wall of the false aneurysm, the aneurys-

\section{Streszczenie}

Tętniak rzekomy lewej komory jest rzadkim powikłaniem aneuryzmektomii. $W$ pracy przedstawiono przypadek tętniaka rzekomego lewej aorty leczonego chirurgicznie, który został zdiagnozowany 3 lata po wykonaniu pomostowania aortalno-wieńcowym oraz aneuryzmektomii lewej komory. Omówiono występujące objawy, ocenę diagnostyczną oraz leczenie chirurgiczne.

Słowa kluczowe: lewokomorowy tętniak rzekomy, masa płuc, aneuryzmektomia.

mal sack was opened and the hole in the antero-apical wall of the left ventricle was closed with several deeply placed 3-0 prolene sutures reinforced by Teflon felt. The patient was easily weaned off bypass. Postoperative transthoracic echocardiography showed no residual communications. The postoperative course was uneventful, and the patient was discharged on the tenth postoperative day. At one-year postoperative follow-up, the patient was in good physical condition.

\section{Discussion}

In this case report a rare complication of left ventricular aneurysmectomy is described. Left ventricular pseudoaneurysms commonly develop as a complication of transmural myocardial infarction (55\%) or cardiac operations, such as mitral valve replacement (33\%), although they may also develop as a result of trauma (7\%), infection of foreign materials such as Teflon felts, myocarditis or endocarditis (5\%), rupture of a true aneurysm, iatrogenic factors such as myocardial biopsy, pericardiocentesis, cardiac catheterization, ablation of accessory pathways and epicardial placement of electrodes [1, 2].

Infrequently, technical failure is identified as a cause of pseudoaneurysm arising in the closure line of ventriculotomy [3]. Occasional cases of pseudoaneurysm after resection of a left ventricular true aneurysm were reported previously [4]. In all of these cases, as in the present case, the pseudoaneurysms developed due to partial dehiscence of sutures after aneurysmectomy. 


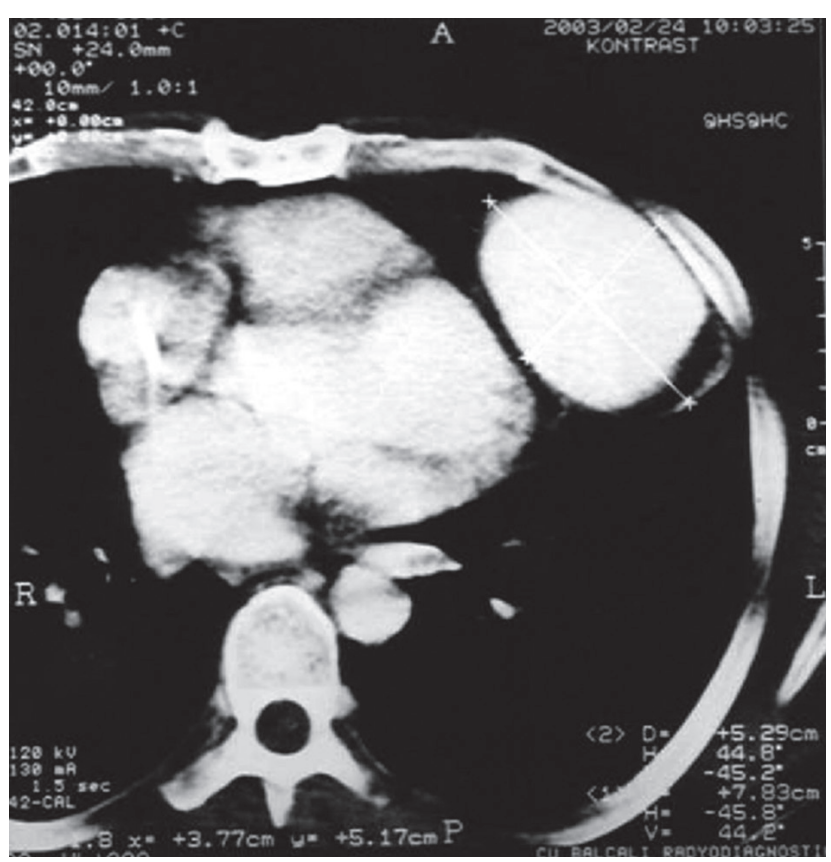

Fig. 1. Computed tomography scan of the chest showing a large left ventricular pseudoaneurysm perceived as a left pulmonary mass

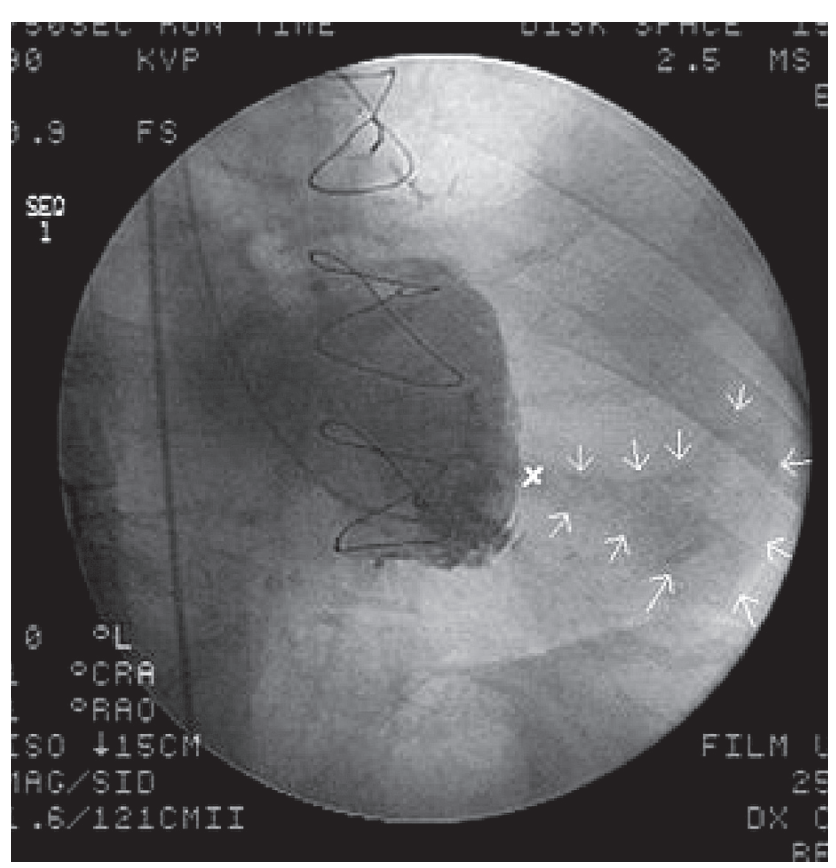

Fig. 3. Left ventriculography (end diastolic frame) showing a pseudoaneurysm and orifice. The arrow points to the pseudoaneurysm (x: orifice)

Although echocardiography, computed tomography scan or magnetic resonance imaging suffices to confirm the diagnosis, left ventriculography was classically described as the diagnostic procedure of choice [3].

The surgical repair of ventricular pseudoaneurysms depends on their origin, size and local extension. Adhesions, presence of bypass grafts and, occasionally, difficult location for surgical access represent the possible technical

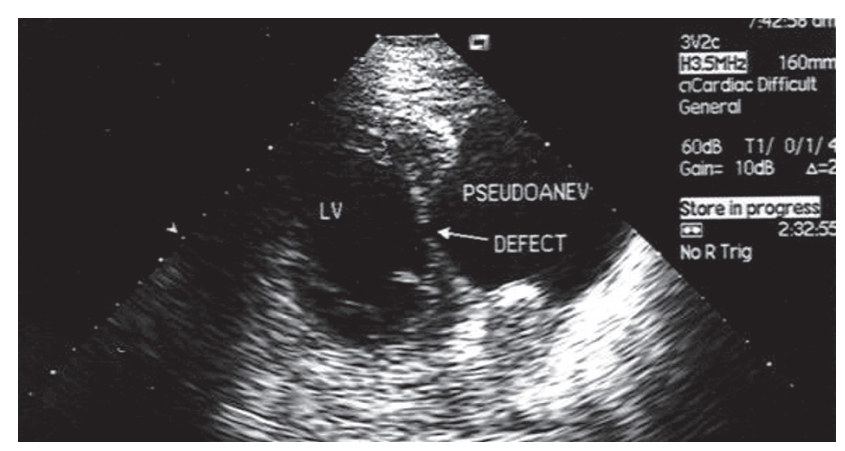

Fig. 2. Transthoracic echocardiography showing a postsurgical left ventricular pseudoaneurysm LV - left ventricle.

difficulties [5]. In the present case, resection of the apicoanterior pseudoaneurysm was easily performed through midline sternotomy by using femoro-femoral cardiopulmonary bypass, moderate systemic hypothermia and antegrade cold-blood cardioplegia. For recurrent large pseudoaneurysms, surgical repair through lateral thoracotomy in deep hypothermic cardiac arrest with low-flow perfusion is also proposed as an alternative [6].

In conclusion, in patients who had left ventriculotomy, the appearance of a postoperative left paracardial mass on the chest X-ray should raise the suspicion of a possible pseudoaneurysm.

\section{Disclosure}

Authors report no conflict of interest.

\section{References}

1. Komeda M, David TE. Surgical treatment of postinfarction false aneurysm of the left ventricle. J Thorac Cardiovasc Surg 1993; 106: 1189-1191.

2. Ruvolo G, Greco E, Speziale G, Di Natale M, Marino B. Surgical repair of pseudo-aneurysm arising from a true chronic aneurysm of the left ventricular lateral wall. Eur J Cardiothorac Surg 1994; 8: 449-450.

3. Davidson KH, Parisi AF, Harrington JJ, Barsamian EM, Fishbein MC. Pseudoaneurysm of the left ventricle: an unusual echocardiographic presentation. Ann Intern Med 1977; 86: 430-433.

4. Rao MS, Vaijyanath P, Taneja K, Dubey B, Manchanda SC, Venugopal P. Recurrent pseudoaneurysm of the left ventricle with subcutaneous herniation into the chest wall. Tex Heart Inst J 1998; 25: 309-311.

5. Prętre R, Linka A, Jenni R, Turina MI. Surgical treatment of acquired left ventricular pseudoaneurysms. Ann Thorac Surg 2000; 70: 553-557.

6. Bauer M, Musci M, Pasic M, Knollmann F, Hetzer R. Surgical treatment of a chest-wall penetrating left ventricular pseudoaneurysm. Ann Thorac Surg 2000; 70: 275-276. 